\title{
EFFECTS OF TIMBER HARVEST ON FOREST LEPIDOPTERA: COMMUNITY, GUILD, AND SPECIES RESPONSES
}

\author{
Keith S. Summerville ${ }^{1}$ AND Thomas O. Crist \\ Department of Zoology, Miami University, Oxford, Ohio 45056 USA
}

\begin{abstract}
Two pressing questions for forestry and conservation biology are whether periodic logging in forest ecosystems significantly changes biodiversity and whether the changes can be mitigated through appropriate harvest methods. Such questions of timber resource management, however, are rarely applied to nonpest insect species, particularly in temperate forest systems. We studied the effects of timber harvest on species richness, abundance, and community composition of forest Lepidoptera (moths). Moths were sampled in 16 forest stands occurring in two watersheds (managed and wilderness) in southeastern Ohio during summer 2000. Stands were chosen from one of four management categories: clear-cut, selectively logged, unlogged, and wilderness. Specifically, we tested the following predictions: (1) shifts in moth community composition would be affected by postharvest changes in stand structure and floristic composition, (2) variation in species richness would be determined by the magnitude of the logging disturbance, and (3) unlogged stands within managed landscapes would contain different species assemblages compared to wilderness stands.

Canonical correspondence analysis (CCA) revealed significant compositional differences among moth communities sampled from forest stands differing in harvest regime. Variation among moth communities was mainly attributable to postharvest changes in stand floristic composition rather than stand structure. Postdisturbance shifts in moth community composition were related to the magnitude of displacement of a given forest stand to earlier successional stages. We also found that both species richness of the overall moth community and several feeding guilds were significantly lower in clear-cut stands, but species richness did not differ between selectively logged and unlogged stands. Thus, selective logging appears to be a better strategy for timber harvest when concern is for maintaining species richness of Lepidoptera within stands. Finally, although no differences were detected in overall species richness or abundance of moths sampled from stands in managed or wilderness watersheds, the CCA suggested that the surrounding landscape influenced the variation in community composition within and among forest stands. Therefore, we suggest that the long-term maintenance of lepidopteran species diversity and community composition within temperate deciduous forests managed for timber may ultimately depend on successful regeneration of harvested stands to precut floristic composition as well as the preservation of larger areas of unlogged forests.
\end{abstract}

Key words: biodiversity; canonical correspondence analysis (CCA); clear-cutting; community composition; disturbance; landscape; Lepidoptera; logging; Ohio; species richness.

\section{INTRODUCTION}

The network of deciduous forests in the eastern stretches of North America is one of the most diverse temperate forest systems on Earth (Latham and Ricklefs 1993, McCarthy et al. 2001). Over the past $200 \mathrm{yr}$, however, eastern forests in the United States have been extensively cleared for agriculture and other land uses, leaving smaller, more isolated woodland remnants interspersed within a human-dominated matrix (Medley et al. 1995, Goebel and Hix 1996). While a few large tracts of continuous eastern deciduous forest are preserved as parks or natural areas, much of the remaining forest in the United States is currently managed for multiple uses, including some form of timber extraction

Manuscript received 24 April 2001; revised 17 August 2001; accepted 21 August 2001.

${ }^{1}$ E-mail: summerks@muohio.edu
(Franklin 1988, Norton 1996). One of the most pressing research questions facing forest ecology today is whether logging significantly changes biodiversity (Ehrlich 1996, Ford et al. 2000). Resolving this question has broad implications for conservation biology and resource management, because the long-term maintenance of biodiversity within harvested systems is a critical component of sustainable forestry goals (e.g., Lubchenco et al. 1991, Andersson et al. 2000).

Despite these concerns, little attention has been given to the status of invertebrate biodiversity in temperate forests (Norton 1996, Lousier 2000). Forest management plans frequently do not place priority on conservation of nonpest insect species (e.g., Holloway 1989, Mrosek 2001). Insects, however, are one of the most diverse and critical components of forest ecosystems (Southwood et al. 1979, Stork 1988). For example, the Lepidoptera (particularly moths) are among the most 
speciose groups of insects that inhabit eastern deciduous forests (Hammond and Miller 1998, Summerville et al. 1999), and forest moth species have important functional roles as selective herbivores, pollinators, detritivores, and prey for migratorial passerines (Schowalter et al. 1986, Perry 1994). Furthermore, the Lepidoptera have shown promise as forest indicator taxa (Kitching et al. 2000) and as surrogates for the diversity of other taxa such as the Hymenoptera (Kerr et al. 2000) or even birds (Blair 1999). Few studies to date, however, have examined how natural factors such as floristic diversity and stand structure or anthropogenic factors such as management history affect the community composition and diversity of temperate forest moths (but see Usher and Keiller [1998], Lepš et al. [1998]).

The responses of tropical insect groups to logging practices suggest several hypotheses for how temperate lepidopteran communities are affected by timber harvest. First, in accordance with the intermediate disturbance hypothesis (Connell 1978), some selectively logged stands increase in floristic diversity and appear to support a higher species richness of Lepidoptera and Coleoptera compared to recently clear-cut or unlogged stands (Nummelin and Hanski 1989, Intachat et al. 1997). More frequently, however, studies have demonstrated that species richness either (1) does not vary greatly between stands regenerating from timber harvest and those left undisturbed (e.g., Holloway et al. 1992, Chey et al. 1997), or (2) is significantly depressed in stands regenerating as a monoculture after a clearcut and only marginally affected by less intensive management strategies (Hamer et al. 1997, Spitzer et al. 1997, Willott 1999, Lewis 2001). Clearly, the effects of logging on lepidopteran biodiversity in tropical forests are not consistent and may depend on the scale of the disturbance (Hill et al. 1995, Hamer and Hill 2000).

In contrast to the idiosyncratic responses of moth species richness and abundance to logging, the composition of moth communities within managed stands appears to be more consistently affected by harvestimposed disturbances. In temperate systems, changes in stand structure and floristic composition following logging are pronounced and long lasting (Duffy and Meier 1992, Arthur et al. 1997, Nagaike et al. 1999, Bhuju and Ohsawa 2001, but see Halpern and Spies [1995], Ford et al. [2000]), and may drive shifts in the community composition of selective herbivores, such as the Lepidoptera. Changes in moth community composition might be predicted by host specialization: the richness of host plant or microhabitat specialists is expected to be impoverished in stands recovering from logging disturbances when the density of their larval host species is sharply reduced, while the species richness of generalists may be unaffected by the loss of one plant resource following logging (Holloway 1989, Spitzer et al. 1997, Willott 1999).

At broader scales, a common forestry practice is to harvest asynchronously large, continuous tracts of woodland, creating a mosaic of stands that are each in different stages of recovery (Gustafson 1996). Often, unlogged stands are allowed to persist within a matrix of heavily managed concessions to serve as potential refugia for species dependent on late-successional, closed-canopy habitats. The role of unlogged stands as species refugia, however, has received empirical consideration only for birds and mammals (Drapeau et al. 2000, Schieck et al. 2000). For these more vagile taxa, locating and dispersing among refugia present little difficulty (e.g., Thiollay 1997). In contrast, dispersal for some Lepidoptera rarely exceeds $0.5 \mathrm{~km}$, and many species may fail to colonize isolated refugia following habitat disturbance (Nieminen 1986). Therefore, studies are needed to determine whether unlogged stands within a harvested matrix support communities of Lepidoptera are similar to those within an unharvested wilderness landscape (defined here as a forest preserve unlogged for $\geq 70 \mathrm{yr}$ with no motor vehicle access) before habitat remnants are appropriately considered species refugia.

In this study, we address the question of whether variation in forest vegetation and stand structure following timber harvest are responsible for changes in lepidopteran biodiversity and community composition. Specifically, we examined and compared the community composition, species richness, and abundance of forest moths occurring in stands that were: clear-cut, selectively logged, or unlogged. First, we tested the hypothesis that shifts in community composition were related to postharvest changes in stand structure and floristic composition (this hypothesis is hereafter denoted "H1"). Next, we tested three alternative hypotheses concerning the effects of logging on moth species diversity: (H2a) timber harvest regime would have no effect on total moth species richness or abundance; (H2b) species richness of moths would be highest in selectively logged stands; and (H2c) species richness of moths would be lower in clear-cut stands, but similar in selectively logged and unlogged stands. We also classified species into feeding guilds to determine if species differed in their responses to logging based on (H3a) larval feeding preferences, or (H3b) degree of larval resource specialization. Finally, we compared moth species diversity and community composition between unlogged stands occurring within two landscapes (a wilderness preserve and a harvested watershed) to test whether (H4) unmanaged stands within managed landscapes function as refugia for forest Lepidoptera.

\section{Methods}

\section{Site selection}

Our study was conducted during May-September 2000 in Shawnee State Forest, Scioto County, Ohio, USA $\left(38^{\circ} 41.45^{\prime} \mathrm{N}, 83^{\circ} 14.67^{\prime} \mathrm{W}\right.$; Fig. 1a). Shawnee State Forest occurs within the unglaciated Allegheny 


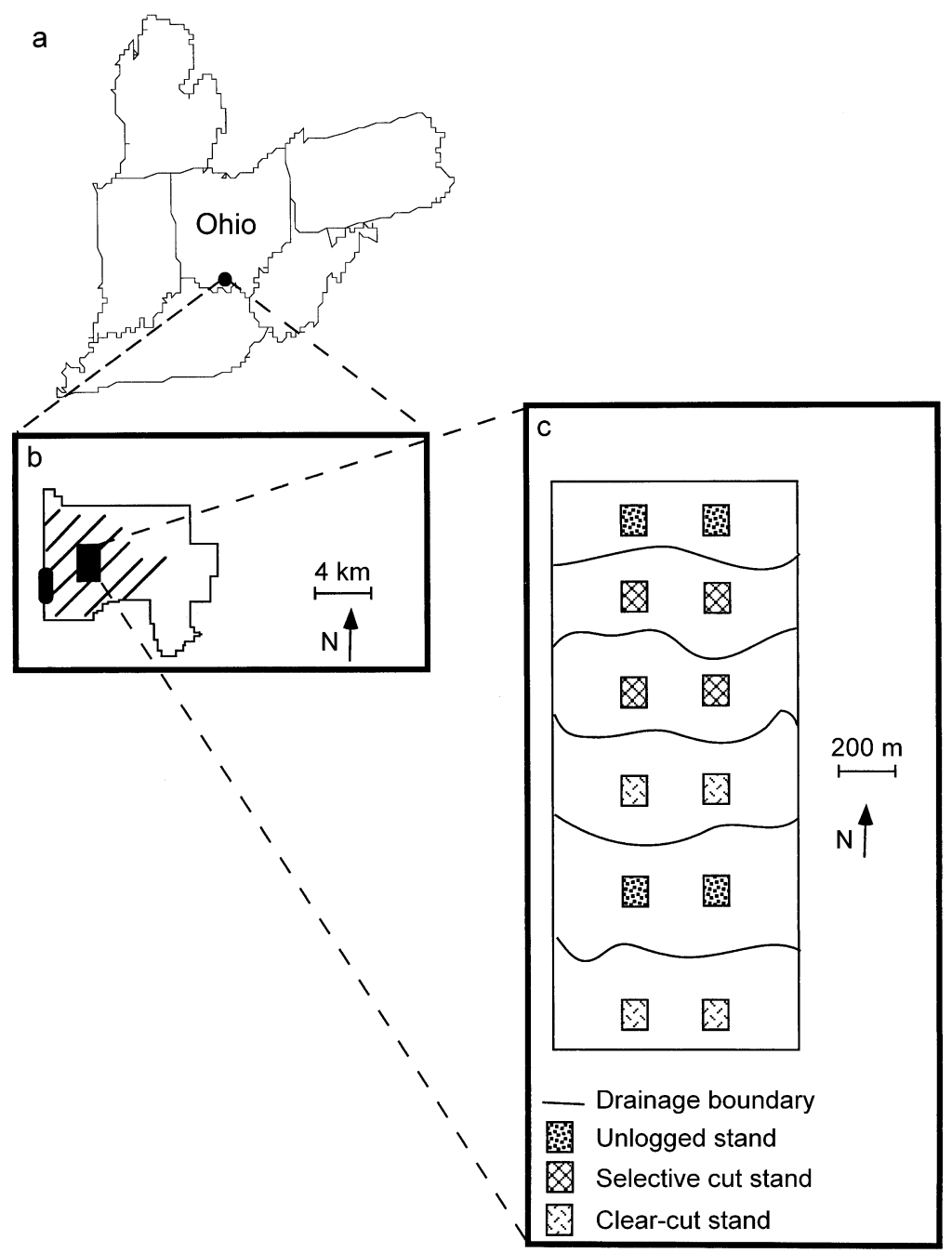

FIG. 1. (a) Map of Ohio, USA, and surrounding states, with location of Shawnee State Forest marked with the solid circle $\left(38^{\circ} 41.45^{\prime} \mathrm{N} ; 83^{\circ} 14.67^{\prime} \mathrm{W}\right)$, and (b) Scioto County, Ohio. (b) Moth sampling was done in two locations in Shawnee State Forest (hatched section) (1, Tarklin Hollow, a watershed managed for timber; $\mathbf{0}$, Vastine Hollow, a wilderness preserve unlogged for $\geq 80 \mathrm{yr}$ ). (c) Schematic of the experimental design used to sample moths from the managed watershed. Drainages were managed with one of three possible harvest techniques: clear-cutting, selective logging, or no logging; and two stands were selected within each drainage for moth sampling.

Plateau, which is characterized by variable topography (steep slopes and narrow drainages), and a parent material that is composed of noncalcareous shales, sandstones (Waverly and Pottsville formations), and other conglomerates (Boerner and Kooser 1989). Combined with the prevailing climate of southern Ohio, these soils naturally support mixed mesophytic forest vegetation (Braun 1961). Oak-hickory (Quercus spp.-Carya spp.) forests dominate many of the ridgetop communities, but drainage valleys frequently contain a high diversity of other species including Eastern hemlock (Tsuga canadensis), yellow poplar (Liriodendron tulipifera), and American basswood (Tilia americana).

The Ohio Division of Forestry manages much of Shawnee State Forest for timber production $(\sim 17000$ ha); however, several large watersheds are maintained as a wil- derness preserve that has not been logged for $\geq 80 \mathrm{yr}$. The land managed for timber production is subdivided into $\sim 50$ watersheds, each 100-300 ha in size. Each watershed is termed a management "compartment," and each compartment is further subdivided into 5-10 drainages that are 30-50 ha in size. Drainages within a compartment are managed independently on a $60-80-\mathrm{yr}$ rotation, with harvest regimes generally falling into three classes: (1) clear-cut harvesting, (2) selective-cut harvesting, and (3) no known harvesting subsequent to 1940 (W. Oney, personal communication). There is some variation in the harvest approach used for selective-cut treatments. In our management compartment, selective logging involved (1) the removal of species less valued for timber or wildlife (e.g., softwoods such as Liriodendron tulipifera or Sassafras albidum), and (2) the harvest of 
economically valuable individuals of Quercus or Carya $(\mathrm{dbh} \geq 30 \mathrm{~cm})$ to allow for continued regeneration of understory mast-producing species. This management prescription minimizes mechanical intrusion into the forest (e.g., from skidders and trucks) and generally involves the removal of one to several trees at any one point. Gaps created by this approach to selective logging seldom exceed 1 ha, although the precise spatial arrangement and size of canopy gaps is highly dependent on the size and species of trees within a stand as well as the specific management goals of the forester (W. Owney, personal communication). Therefore, stands within a compartment are in different stages of rotation, resulting in a mosaic of stand ages.

We sampled forest moths in a single managed compartment (Tarklin Hollow, 38 $41.45^{\prime} \mathrm{N} ; 8^{\circ} 14.67^{\prime} \mathrm{W}$ ) and a single watershed maintained as undisturbed wilderness since 1925 (Vastine Hollow, 38³9.77' N, $\left.83^{\circ} 16.64^{\prime} \mathrm{W}\right)$. The managed compartment contained a total of six drainages, of which two were clear-cut in 1985-1986, two were selectively logged in 1987, and two were left unlogged since 1945 (Fig. 1b). Two stands $(\sim 2$ ha) within each drainage were selected for sampling, with the minimum distance between stands $\geq 200 \mathrm{~m}$ (a total of 12 stands). To compare unlogged stands in managed and unmanaged landscapes, we also selected two drainages (i.e., 4 stands) within the wilderness preserve for Lepidoptera sampling. To control for possible effects of topographic aspect, we selected drainages having a north or north-northeast aspect. Furthermore, to control for possible effects of elevation on moth and plant communities, we selected stands occurring within a narrow range of elevations (275$325 \mathrm{~m})$.

\section{Moth sampling}

Within each forest stand, we sampled Lepidoptera using a single 12-W universal blacklight trap (model 2851T; BioQuip, Gardena, California, USA) powered by a $12-\mathrm{V}$ (26 A.h) gel battery. Blacklight traps are widely considered to be the standard technique for sampling moth communities, although the method is biased toward collecting phototactic species (Southwood 1978). Thus, species whose activity is primarily diurnal and species whose adults are attracted only to sugar or pheromone bait were not sampled using this method (see Summerville et al. 2001). Traps were positioned on trap stations $\sim 2 \mathrm{~m}$ above the ground. Trap stations were constructed by attaching a small plywood platform to a stake that was driven into the soil. Moths attracted to the ultraviolet (UV) lights were sacrificed inside the traps using ethyl acetate and Dichlorvos (product no. 1196; BioQuip, Gardena, California, USA) killing agents.

Lepidoptera were sampled during June and August 2000 to accommodate phenological variation in community composition and species diversity. In temperate forest systems, these months correspond to peaks in species richness (Rings et al. 1992, Thomas and Thomas 1994), and stratifying sampling by season allowed us to analyze the effects of management practices on moth communities within the context of natural phenological variation. Traps were operated within each stand for two nonconsecutive nights during the hours of 1930-0600 Eastern Daylight Time, during both early and late seasons (four nights total per stand). Therefore, 64 samples were collected in early and late seasons combined. Weather has a significant effect on moth flight behavior and light trap efficiency, so we sampled only on nights when minimum temperature was 15.5 $17.5^{\circ} \mathrm{C}$, there was no precipitation, and ambient moonlight was low (i.e., moon phases, half-new) as recommended by Yela and Holyoak (1997). On a given sampling night, four stands were randomly selected for sampling, such that one stand from each treatment was represented. Despite the restrictions on our sampling protocol, we obtained complete sampling rotations for all 16 stands in 7-10 d.

Collected specimens were frozen after trap processing to facilitate curation and identification. Individuals were identified to species when possible, using available taxonomic keys and vouchered specimens in museum collections. Specimen determinations of Tortricidae, Pyralidoidea, and Gelechioidea were verified or performed by recognized experts. For several poorly known taxa (e.g., Bucculatracidae), we sorted individuals into morphospecies (sensu Oliver and Beattie 1996) as suggested by Robinson and Tuck (1993). Unnamed morphospecies comprised only $12 \%$ of our species total, and we verified our morphospecies rankings with recognized taxonomic experts to reduce error due to splitting or lumping of superficially similar taxa.

\section{Vegetation sampling}

In May-June 2000, we sampled the plant community of each forest stand using a series of nested quadrats. Each series was designed such that, within a stand, one set of quadrats was centered on the position of the lighttrapping station and the remaining two were randomly located $50 \mathrm{~m}$ from center. The largest quadrat in each series $(20 \times 20 \mathrm{~m})$ was used to quantify species richness, abundance, and diameter at breast height of all trees $>10 \mathrm{~cm}$ dbh. Canopy cover was measured using a densiometer and determining the number of "hits," $m$, of foliage at nine points (cover $=[\mathrm{m} / 9][100 \%])$ spaced at $10-\mathrm{m}$ intervals along the perimeter of each $20 \times 20 \mathrm{~m}$ quadrat. To form smaller quadrats, each 20 $\times 20 \mathrm{~m}$ quadrat was subdivided into four contiguous $10 \times 10 \mathrm{~m}$ squares. Two squares were randomly chosen along the diagonal, and a $5 \times 5 \mathrm{~m}$ quadrat was centered in each square. Species richness and abundance of shrubs and saplings were measured within each of these $5 \times 5 \mathrm{~m}$ quadrats. Species richness, abundance, and percent cover of vegetation within the herbaceous layer were measured within two $1-\mathrm{m}^{2}$ quadrats nested within each shrub plot. 
TABLE 1. Summary of vegetation data collected from nested quadrat sampling within forest stands of Shawnee State Forest.

\begin{tabular}{llcc}
\hline \hline & & \multicolumn{2}{c}{ Vegetation parameter measured } \\
\cline { 2 - 4 } Forest layer & Floristic diversity & Structural attributes & Species attributes \\
\hline Trees & species richness & canopy cover & species importance values \\
& Simpson's index & standard basal area & $\ldots$ \\
Shrubs & stand density & $\ldots$ \\
& Species richness & $\ldots$ & species importance values \\
Herbs & Simpson's index & $\ldots$ & $\ldots$ \\
& Species richness & herbaceous cover & species importance values \\
& Simpson's index & $\ldots$ & $\ldots$ \\
\hline
\end{tabular}

Plant data collected from nested quadrat sampling were used to calculate a number of variables to describe the structure and composition of each forest stand. Diameter-at-breast-height values for the trees were used to calculate stand basal area (in units of square meters per hectare). Mean canopy cover for each stand was calculated as the average of the cover estimates from each large quadrat in the series. Stand density was determined as the number of stems per hectare. To account for potential variation in species dominance among stands, the relative abundances of each plant species were used to calculate Simpson's index of species diversity for each structural layer of the forest (e.g., tree, shrub, herb). In addition, we calculated importance percentages for each tree species sampled within the forest stands. An importance percentage (IP) is simply the mean of three relative values determined for each tree species: basal area, abundance, and frequency (Greig-Smith 1983, Bonham 1989). The relative frequency of a given species is the number of 20 $\times 20 \mathrm{~m}$ quadrats within a stand in which the species was sampled $(n / 3)$, providing an estimate for the spatial distribution of each tree species within a stand. Species found within all three large quadrats within a stand generally have a higher weight in the calculation of importance than species that are patchily distributed (Greig-Smith 1983). Tree species that have an IP value near unity are the largest, most abundant, and widely distributed species within the stand. Importance percentages for shrub and herbaceous species were calculated as for tree species, except without basal area. A summary of vegetation data collected as a result of nested quadrat sampling is provided in Tables $1-3$.

\section{Data analysis}

Guild classification.-Moth species richness and abundance data were combined between the two sampling nights for each stand in early and late season to produce aggregate stand values. Pooling data across nights within each season was performed because light trap samples collected $<10 \mathrm{~d}$ apart may not be independent (Thomas and Thomas 1994). We assigned moth species to general feeding guilds based upon plant life form or other favored larval host types: (1) woody plant feeders (WP), (2) forb and graminoid feeders
(HERB), (3) dead/decaying vegetation feeders (DET), (4) fungi/lichen/moss feeders (FLM), and (5) generalized feeders utilizing more than one host categories (GEN). Although other studies of moth communities have not used such a broad guild classification, we were interested in how moth community structure was affected by variation in food resource availability among managed stands. To facilitate comparison with published studies, moth species whose caterpillars were woody plant feeders (the most species-rich group in our study) were further classified as specialized (using species within one genus of host plant), oligophagous (using several genera within one family of host plants), or generalist (using species from a variety of plant families) (see Lepš et al. [1998]). Both guild classifications were based on published species life histories from the Wedge Entomological Foundation's Moths of North America project (see Dominick et al. 1976) or from other taxonomic and ecological sources (Forbes 1923, Heinrich 1956, McGuffin 1972, 1977, 1981, 1987, Mackay 1959, 1962, Braun 1963, 1972, Tietz 1972, Wilkinson and Scoble 1979, Covell 1983, Miller 1987). These sources represent the best and most complete sources of information available on host plant affiliations for moth species. For example, Tietz (1972) indexes $>80 \mathrm{yr}$ of published host plant information for macrolepidoptera. Host plant information may be incomplete for some taxa, however, especially microlepidoptera. The effects underestimating the diet breadth of some species would be to artificially inflate the number of specialists, and the response of specialists to timber management may be masked or biased by "false specialists" whose caterpillars are capable (but undocumented) of feeding on a larger number of host plants. Species lacking published life histories were classified as unknown and excluded from guild-level analyses.

Statistical tests.-We assessed variation in moth community composition among stands and examined this variation to floristic differences among stands using canonical correspondence analysis (H1). Canonical correspondence analysis (CCA) is a multivariate technique that ordinates sites using both a primary matrix of species abundances among sites and a secondary matrix of environmental variation among sites (ter Braak 1986). A detailed treatment of CCA may be 
TABLE 2. Observed variation in tree species composition (i.e., "importance") among forest stands differing in timber management. Values reported are mean importance (1 SD).

\begin{tabular}{|c|c|c|c|c|}
\hline \multirow[b]{2}{*}{ Tree species $\dagger$} & \multicolumn{4}{|c|}{ Tree community composition } \\
\hline & Clear-cut & Selective cut & Unlogged & Wilderness \\
\hline Liriodendron tulipifera & $0.264(0.03)$ & $0.181(0.09)$ & $0.163(0.05)$ & $0.086(0.01)$ \\
\hline Prunus serotina & $0.200(0.05)$ & $0.090(0.04)$ & $0.000(0.00)$ & $0.000(0.00)$ \\
\hline Acer rubrum & $0.149(0.04)$ & $0.252(0.09)$ & $0.125(0.05)$ & $0.178(0.02)$ \\
\hline Robinia pseudoacacia & $0.075(0.02)$ & $0.007(0.01)$ & $0.000(0.00)$ & $0.000(0.00)$ \\
\hline Sassafras albidum & $0.066(0.02)$ & $0.020(0.02)$ & $0.016(0.02)$ & $0.043(0.05)$ \\
\hline Quercus velutina & $0.049(0.04)$ & $0.075(0.03)$ & $0.178(0.06)$ & $0.081(0.04)$ \\
\hline Quercus montana & $0.039(0.04)$ & $0.077(0.10)$ & $0.183(0.07)$ & $0.086(0.10)$ \\
\hline Tilia americana & $0.036(0.01)$ & $0.022(0.04)$ & $0.007(0.01)$ & $0.030(0.04)$ \\
\hline Nyssa sylvatica & $0.033(0.03)$ & $0.059(0.03)$ & $0.050(0.04)$ & $0.039(0.03)$ \\
\hline Fraxinus americana & $0.030(0.02)$ & $0.021(0.02)$ & $0.000(0.00)$ & $0.009(0.02)$ \\
\hline Crataegus sp. & $0.028(0.02)$ & $0.000(0.00)$ & $0.000(0.00)$ & $0.000(0.00)$ \\
\hline Quercus alba & $0.016(0.01)$ & $0.075(0.05)$ & $0.118(0.05)$ & $0.163(0.03)$ \\
\hline Rhus glabra & $0.013(0.01)$ & $0.000(0.00)$ & $0.000(0.00)$ & $0.000(0.00)$ \\
\hline Cercis canadensis & $0.007(0.12)$ & $0.000(0.00)$ & $0.000(0.00)$ & $0.000(0.00)$ \\
\hline Carya glabra & $0.000(0.00)$ & $0.013(0.02)$ & $0.014(0.02)$ & $0.036(0.01)$ \\
\hline Carya ovata & $0.000(0.00)$ & $0.000(0.00)$ & $0.029(0.03)$ & $0.014(0.02)$ \\
\hline Carya tomentosa & $0.000(0.00)$ & $0.046(0.03)$ & $0.049(0.03)$ & $0.095(0.05)$ \\
\hline Cornus florida & $0.000(0.00)$ & $0.007(0.01)$ & $0.000(0.00)$ & $0.013(0.02)$ \\
\hline Fagus gradifolia & $0.00(0.00)$ & $0.000(0.00)$ & $0.000(0.00)$ & $0.024(0.03)$ \\
\hline Juglans nigra & $0.000(0.00)$ & $0.000(0.00)$ & $0.000(0.00)$ & $0.020(0.02)$ \\
\hline Quercus coccinea & $0.000(0.00)$ & $0.000(0.00)$ & $0.000(0.00)$ & $0.010(0.01)$ \\
\hline Quercus muehlenbergii & $0.000(0.00)$ & $0.047(0.05)$ & $0.017(0.02)$ & $0.036(0.02)$ \\
\hline Quercus rubra & $0.000(0.00)$ & $0.009(0.01)$ & $0.050(0.05)$ & $0.025(0.03)$ \\
\hline Ulmus rubra & $0.000(0.00)$ & $0.000(0.00)$ & $0.000(0.00)$ & $0.010(0.01)$ \\
\hline
\end{tabular}

Notes: Four replicate stands were allocated to each level of harvest technique. Tree species are arranged according to decreasing importance relative to the clear-cut treatment. Oaks and hickories (species marked in bold) attained a higher overall importance in less intensively managed stands.

$\dagger$ Nomenclature follows Braun (1961).

found in Jongman et al. (1995). Briefly, the algorithm for CCA defines linear combinations of environmental variables that maximize the separation distance between species responses on synthetic ordination axes (ter Braak 1994). In ordination space, site scores are weighted averages of species scores and are plotted in the center of the cluster of species occurring at that site. Thus, species whose scores are close to a given site point in the ordination are likely to attain a high abundance at that site. The positions of site scores in the area created by the ordination axes shows how overall community structure varies with the combination of measured environmental variables. The influence of the environmental variables on community structure can be qualitatively modeled on the ordination figure through the use of biplots, which are graphic renderings of species-environment correlations (ter Braak 1994).

We performed CCA in PC-ORD (version 4.0, MJM
Software Design 1999). To measure the overall community response to forest management regime, we combined early and late season species abundance data for each stand to produce composite stand totals (ordinations within seasons yielded similar results; K. S. Summerville and T. O. Crist, unpublished data). Data were log-transformed to down weight the contribution of several highly abundant species on community structure. The secondary matrix consisted of the vegetation data sampled within each stand (Table 1) and an indicator variable for drainage location to assess how spatial position within a watershed might influence lepidopteran community composition. Thus, our analysis did not directly use a variable for harvest regime, but rather indirectly examined harvest levels through variation in vegetation among stands. Because CCA may be sensitive to the "arch-effect" when many redundant environmental variables are used (see Jongman et al.

TABLE 3. Observed variation in structure attributes among forest stands differing in timber management. Values reported are means (1 SD).

\begin{tabular}{lcccc}
\hline \hline & \multicolumn{4}{c}{ Forest stand structure } \\
\cline { 2 - 5 } \multicolumn{1}{c}{ Structural attribute } & Clear-cut & Selective cut & Unlogged & Wilderness \\
\hline Basal area $\left(\mathrm{m}^{2} / \mathrm{ha}\right)$ & $14.7(1.1)$ & $22.4(4.2)$ & $44.1(4.0)$ & $36.7(3.5)$ \\
Tree density $($ no. individuals/ha) & $416.5(45.1)$ & $277.0(66.8)$ & $237.5(31.3)$ & $302.1(40.5)$ \\
Canopy cover $(\%)$ & $67.0(23.1)$ & $61.2(4.8)$ & $66.8(2.9)$ & $66.5(7.0)$ \\
\hline
\end{tabular}

Note: Four replicate stands were allocated to each level of harvest techniques. 
1995), we removed extraneous variables through a process of backwards elimination based on preliminary CCA runs (ter Braak 1986). To assess the significance of the CCA axes, we used the Monte Carlo simulation in PC-ORD to test the hypothesis that there was no correlation between the primary and secondary matrices. We used a conservative $r^{2}$ value $(0.25$; see ter Braak [1994]) as the minimum level of species-environment correlation for biplot display on the final CCA ordination diagram. Finally, we plotted the positions of only selected species in CCA space to determine how species of conservation or management interest were affected by logging.

Differences in species richness and abundance of forest moths among stands differing in management history were tested using a two-level nested analysis of variance (ANOVA) model (PROC GLM procedure; SAS Institute 1996). We considered harvest level (clear cut, selective cut, unlogged, or wilderness) as the main effect, drainage as nested within harvest, and stands as nested within drainage. To conduct hypothesis tests, the main effect of timber harvest was tested using drainage within harvest as the error term ("error $a$ "), and drainage within harvest was tested using stand within drainage as the overall model error term ("error b") (Sokal and Rohlf 1995). Species abundances were log-transformed prior to analysis to stabilize variances and normalize the data. We used Tukey's post-hoc tests (Neter et al.1990) to assess differences in richness and abundance among treatments. In contrast to CCA, separate ANOVA models were used for early- and lateseason moth communities to examine temporal variation in lepidopteran species richness and abundance. Significant differences in overall species richness among forest stands were examined in more detail by testing for differences in species richness among families with $>20$ species. Separate ANOVA models were also used to test for differences in moth species richness and abundance among forest stands within the logged compartment $(\mathrm{H} 2 \mathrm{a}-\mathrm{c})$ and between unlogged stands in managed and unmanaged landscapes (H4). This approach differs from our CCA (all treatments analyzed simultaneously) in that differences between wilderness stands and unlogged stands in the managed compartment were examined independently of the other management levels. We chose these two approaches to the data analysis because the CCA was aimed at assessing overall variation in moth community composition among all forest stands, while the ANOVA models were used to quantify differences among managed stands or between managed and unmanaged landscapes. We also used the nested ANOVA model to test for differences in richness and abundance of moths assigned to one of the five general feeding guilds that we have described $(\mathrm{H} 3 \mathrm{a})$.

Finally, we used a log-linear model to test for differential responses to timber harvest among species that were generalist, oligophagous, or specialist con-
TABLE 4. Number of species and individuals of forest Lepidoptera sampled in Shawnee State Forest.

\begin{tabular}{|c|c|c|}
\hline Family & No. species & No individuals \\
\hline Apatelodidae & 2 & 23 \\
\hline Arctiidae & 20 & 4399 \\
\hline Blastobasidae & 7 & 160 \\
\hline Coleophoridae & 4 & 10 \\
\hline Cosmopterigidae & 5 & 54 \\
\hline Cossidae & 1 & 1 \\
\hline Drepanidae & 1 & 3 \\
\hline Epiplemidae & 1 & 31 \\
\hline Epipyropidae & 1 & 12 \\
\hline Gelechiidae & 27 & 975 \\
\hline Geometridae & 71 & 3087 \\
\hline Gracillariidae & 9 & 34 \\
\hline Lasiocampidae & 2 & 2311 \\
\hline Limacodidae & 13 & 108 \\
\hline Lymantriidae & 5 & 239 \\
\hline Lyonetiidae & 14 & 98 \\
\hline Megalopigidae & 1 & 114 \\
\hline Mimallonidae & 1 & 21 \\
\hline Momphidae & 1 & 7 \\
\hline Nepticulidae & 2 & 3 \\
\hline Noctuidae & 141 & 5117 \\
\hline Notodontidae & 23 & 1056 \\
\hline Oecophoridae & 17 & 245 \\
\hline Ospostegidae & 1 & 4 \\
\hline Pterophoridae & 2 & 23 \\
\hline Pyralidae & 62 & 4823 \\
\hline Saturniidae & 8 & 219 \\
\hline Sessiidae & 1 & 4 \\
\hline Sphingidae & 4 & 27 \\
\hline Thyatiridae & 1 & 1 \\
\hline Tineidae & 9 & 86 \\
\hline Tisheriidae & 1 & 2 \\
\hline Tortricidae & 50 & 1073 \\
\hline Yponmeutidae & 2 & 18 \\
\hline Zygaenidae & 2 & 397 \\
\hline Total & 512 & 24785 \\
\hline
\end{tabular}

Note: Data are arranged according to family and are listed in alphabetical order.

sumers of woody plant foliage (H3b). Numbers of generalist, oligophagous, and specialist species were analyzed in a three-way log-linear model (PROC CATMOD; SAS Institute 1996) that considered the main effects of harvest regime ( $\mathrm{df}=2$ ), feeding classification $(\mathrm{df}=2)$, and their interaction $(\mathrm{df}=4)$. A significant interaction term would suggest that species with specialized host plant requirements were disproportionately affected by timber harvest. We developed only log-linear models for species sampled from the managed watershed.

\section{RESUlts}

\section{Effects of timber harvest on moth community composition $(\mathrm{Hl})$}

A total of 512 moth species and 24785 individuals were sampled from Shawnee State Forest in 2000 (Table 4). We found significant differences in species composition among moth communities sampled from forest stands differing in harvest regimes. Canonical correspondence analysis (CCA) grouped stands into four distinct clusters in ordination space; each cluster rep- 

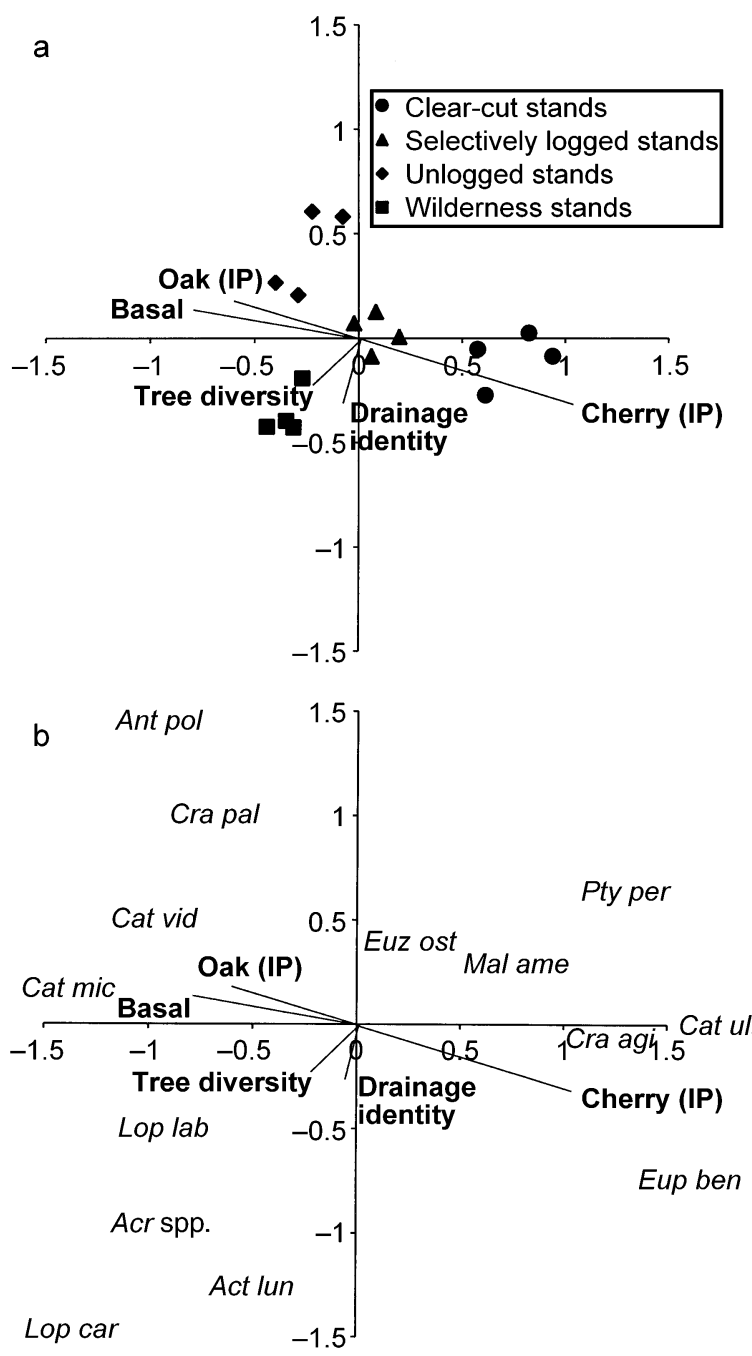

FIG. 2. Canonical correspondence analysis (CCA) of 16 forest stands in Shawnee State Forest and 513 moth species. (a) Stands clustered in ordination space according to their harvest regime. The differences among stands were correlated with five environmental variables: oak importance (Oak IP), stand basal area (Basal), Simpson's diversity of trees (TDIV), drainage identity, and cherry importance (Cherry IP). (b) Species-environment relationships depicted in ordination space. Species abbreviations are as follows: Ant pol, Antheraea polyphemus; Cra pal, Crambidia pallida; Cat vid, Catocala vidua; Cat mic, Catocala micronympha; Lop lab, Lophosis labeculata; Acr spp., Acrobasis species complex; Act lun, Actias luna; Lop car, Lophocampa caryae; Euz ost, Euzophera osticolorella; Mal ame, Malacosoma americanum; Pty per, Ptychloma peritana; Cra agi, Crambus agitatellus; Cat ult, Catocala ultronia; Eup ben, Euplexia benesimilis.

resenting stands harvested using similar extraction techniques (Fig. 2a). The canonical eigenvalues of the first three ordination axes were significant $(P<0.05)$, and the overall CCA (first 3 axes) explained $\sim 30 \%$ of the total variance among the forest moth communities (Table 5). Five environmental variables contributed to the separation of moth communities in ordination space: oak importance (Oak IP, calculated as the sum of individual oak species' importance values; Table 2), stand basal area (SBA; Table 3), tree diversity (TDIV, Simpson's index for tree species diversity), cherry importance (Cherry IP; Table 2), and drainage identity (an indicator of the spatial position of each drainage within the watersheds) $\left(r^{2}>0.25\right)$. Of these variables, Oak IP, SBA, and Cherry IP appeared to differentiate among stands within the logged watershed. In general, unlogged stands had a larger basal area and were dominated by oaks and, to a lesser degree, hickories (e.g., Quercus velutina, $Q$. alba, Q. montana, Carya spp.; Tables 2 and 3), whereas recently clear-cut stands contained smaller trees and a greater importance of early successional species (e.g., black cherry, Prunus serotina; sassafras, Sassafras albidum; Tables 2 and 3). The variables TDIV and drainage identity were correlated with axis 2, and represent interstand heterogeneity in floristic composition and landscape position (e.g., managed vs. unmanaged watershed; Fig. 2a). The use of drainage identity in the CCA may have led to a greater separation in moth community composition between stands located in different watersheds (wilderness and unlogged stands). As a check, we also performed a detrended correspondence analysis (DCA) to determine how moth community composition alone varied across all 16 stands (analysis not shown). Even though DCA does not incorporate vegetation and spatial variables, the analysis still separated the 16 stands into four separate clusters, each corresponding to individual management treatments. In the CCA, interstand heterogeneity in moth communities appeared the most significant for unlogged and clear-cut stands in the managed watershed because the site scores for the selectively logged and wilderness stands were highly clustered in ordination space. Finally, the central position of the site scores for the selectively logged stands on the CCA diagram suggests that forest patches managed under this harvest regime contain a mixture of moth species

TABLE 5. Summary of the canonical correspondence analysis (CCA) of moth communities sampled in Shawnee State Forest, Ohio.

\begin{tabular}{|c|c|c|c|c|}
\hline $\begin{array}{l}\text { Ordination } \\
\text { axis }\end{array}$ & $\begin{array}{c}\text { Eigen- } \\
\text { value }\end{array}$ & $\begin{array}{c}\text { Variance } \\
\text { explained } \\
\text { by axis }(\%)\end{array}$ & $\begin{array}{c}\text { Cumulative } \\
\text { variance } \\
\text { explained } \\
(\%)\end{array}$ & $P$ \\
\hline Axis 1 & 0.168 & 13.4 & 13.4 & 0.001 \\
\hline Axis 2 & 0.101 & 8.1 & 21.5 & 0.033 \\
\hline Axis 3 & 0.091 & 7.2 & 28.7 & 0.045 \\
\hline
\end{tabular}

Notes: The canonical eigenvalue was 0.360 . The first three ordination axes had significant canonical eigenvalues (as determined by a Monte Carlo test), and the overall CCA explained $29 \%$ of the total variance in month communities among forest stands managed with different timber harvest regimes. Results of CCA are shown in Fig. 2; $P$ values are based on the proportion of 1000 Monte Carlo simulations with eigenvalue greater than the observed eigenvalue. 
TABLE 6. Two-level nested ANOVA for differences in mean species richness and log-transformed abundance of Lepidoptera sampled in 12 stands within a watershed managed for timber production.

\begin{tabular}{|c|c|c|c|c|c|}
\hline \multirow[b]{2}{*}{ Variable } & \multicolumn{2}{|c|}{ Harvest $(\mathrm{df}=2)$} & \multicolumn{2}{|c|}{$\begin{array}{l}\text { Drainage(harvest) } \\
(\mathrm{df}=3)(\text { error } a)\end{array}$} & \multirow{2}{*}{$\begin{array}{c}\text { Stand } \\
(\text { drainage }) \\
(\mathrm{df}=6) \\
(\text { error } b)\end{array}$} \\
\hline & MS & $F$ & MS & $F$ & \\
\hline \multicolumn{6}{|c|}{ Community responses } \\
\hline \multicolumn{6}{|c|}{ Species richness } \\
\hline Early & 1439.6 & $17.33^{*}$ & 83.10 & 1.82 & 45.75 \\
\hline Late & 937.3 & $16.66^{*}$ & 56.25 & 0.41 & 137.58 \\
\hline \multicolumn{6}{|l|}{ Abundance } \\
\hline Early & 0.31 & 0.75 & 0.042 & 1.08 & 0.039 \\
\hline Late & 0.64 & $10.31 *$ & 0.062 & 1.89 & 0.033 \\
\hline \multicolumn{6}{|c|}{ Family responses } \\
\hline \multicolumn{6}{|l|}{ Arctiidae } \\
\hline Early & 25.08 & $16.72 *$ & 1.50 & 1.12 & 1.33 \\
\hline Late & 0.58 & 3.50 & 0.17 & 0.50 & 0.33 \\
\hline \multicolumn{6}{|l|}{ Gelechiidae } \\
\hline Early & 1.00 & 0.44 & 2.25 & 1.80 & 1.25 \\
\hline Late & 2.25 & 1.04 & 2.17 & 2.60 & 0.84 \\
\hline \multicolumn{6}{|c|}{ Geometridae } \\
\hline Early & 69.33 & $5.82 *$ & 13.58 & 1.14 & 11.91 \\
\hline Late & 26.08 & 8.06 & 3.08 & 0.39 & 7.91 \\
\hline \multicolumn{6}{|l|}{ Noctuidae } \\
\hline Early & 28.00 & 0.65 & 42.91 & $9.36^{*}$ & 4.58 \\
\hline Late & 300.1 & $51.44 * *$ & 5.83 & 0.39 & 15.0 \\
\hline \multicolumn{6}{|c|}{ Notodontidae } \\
\hline Early & 52.58 & $126.2 * * *$ & 0.42 & 0.11 & 3.75 \\
\hline Late & 66.08 & $396.5 * * * *$ & 0.17 & 0.20 & 0.83 \\
\hline \multicolumn{6}{|l|}{ Pyralidae } \\
\hline Early & 13.58 & 3.33 & 4.08 & 0.62 & 6.58 \\
\hline Late & 6.75 & 0.60 & 11.16 & 2.09 & 5.33 \\
\hline \multicolumn{6}{|l|}{ Tortricidae } \\
\hline Early & 1.00 & 0.60 & 1.67 & 0.59 & 2.83 \\
\hline Late & 5.25 & 0.56 & 9.42 & 1.92 & 4.92 \\
\hline
\end{tabular}

Notes: Differences in mean species richness for families with $>20$ species were also analyzed to assess whether particular groups responded differently to harvest. Error $a$ was used as the denominator in the $F$ statistic to test the main effect of harvest. Error $b$ was used to test the nested effect of Drainage(harvest) (see Sokal and Rohlf 1995).

$* P<0.05 ; * * P<0.01 ; * * * P<0.001 ; * * * * P<0.0001$

that are characteristic of both unlogged and clear-cut forest patches.

The CCA also allowed us to examine patterns in species dominance among forest moth communities (Fig. 2b). Moth communities in clear-cut stands were composed of species with caterpillars that prefer early successional tree species. For example, larvae of $\mathrm{Ca}$ tocala ultronia and Malacosoma americanum prefer feeding on leaves of Prunus spp., and the scores of these species grouped near the site scores of the clearcut stands in ordination space. In addition, generalist consumers of herbaceous vegetation such as Crambus agitatellis, Ptycholma peritana, and Euplexia benesimilis attained their highest abundance in clear-cut stands. In contrast, unlogged and wilderness stands were dominated by: (1) Quercus and Carya phytophages (e.g., Catocala micronympha, Catocala vidua, Acrobasis spp. complex [stigmella, paliolella, caryae, kearfotella, demotella], Lophocampa caryae), (2) acorn seed predators (e.g., Blastobasis glandulella), and (3) fungi or lichen feeders (e.g., Crambidia pallida). Fur- thermore, large-bodied saturniid species (Actias luna, Antheraea polyphemus) were almost exclusively found in unlogged or selectively cut stands. Finally, several potentially rare species in Ohio (e.g., Lophosis labeculata, a geometrid immigrant from southern states) were only found in wilderness stands (Fig. 2b). Thus, the CCA suggests that variation in moth community composition can be explained, in part, by species' responses to changes in host plant availability following logging.

\section{Effects of timber harvest on moth species richness and abundance $(\mathrm{H} 2 \mathrm{a}-\mathrm{c})$}

Nested ANOVA models showed that overall species richness and abundance of forest Lepidoptera differed among stands in the managed watershed (Table 6). In the early season, significantly higher species richness was observed in unlogged stands compared to selectively logged or clear-cut stands (Fig. 3a). By the late season, however, richness differences between selectively logged and unlogged stands had disappeared, 

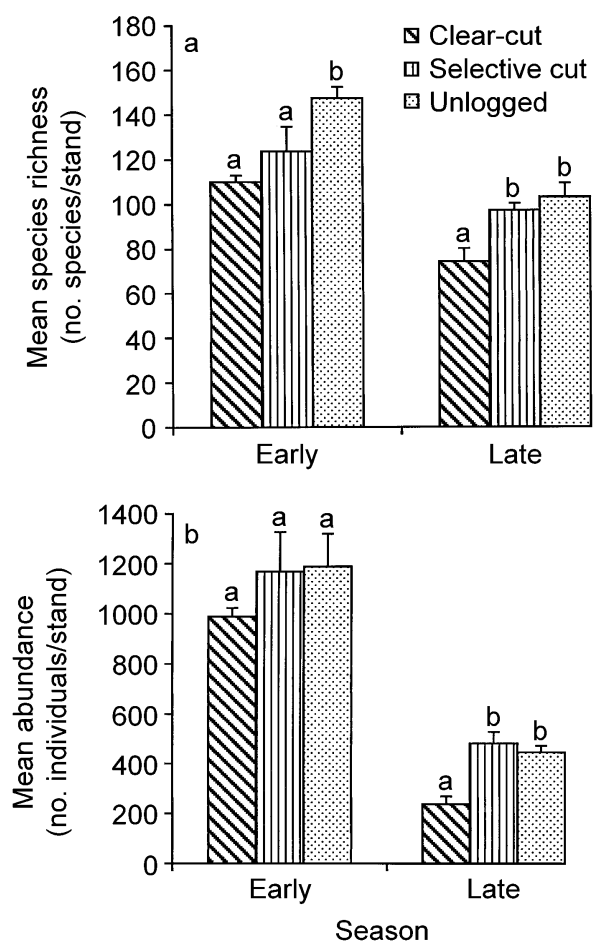

FIG. 3. Responses of (a) moth species richness and (b) abundance of moths to timber harvest $(+1 \mathrm{SE})$. Community response varied with intensity of the harvest regime and season. Means with different letters are significantly different (Tukey's post hoc tests, $P<0.05$ ).

with clear-cut stands still having significantly fewer species (Fig. 3a). Among moth families with $\geq 20$ species, species richness of Arctiidae, Geometridae, Noctuidae, and Notodontidae did not differ between unlogged or selectively logged stands, but was significantly lower in clear-cut stands (depending on season, see Table 6). The difference for notodontids was the most disparate; unlogged and selectively logged stands contained, on average, three to four times as many species as clear-cut stands. The nested effect of drainages within harvest regime was nonsignificant in mod-

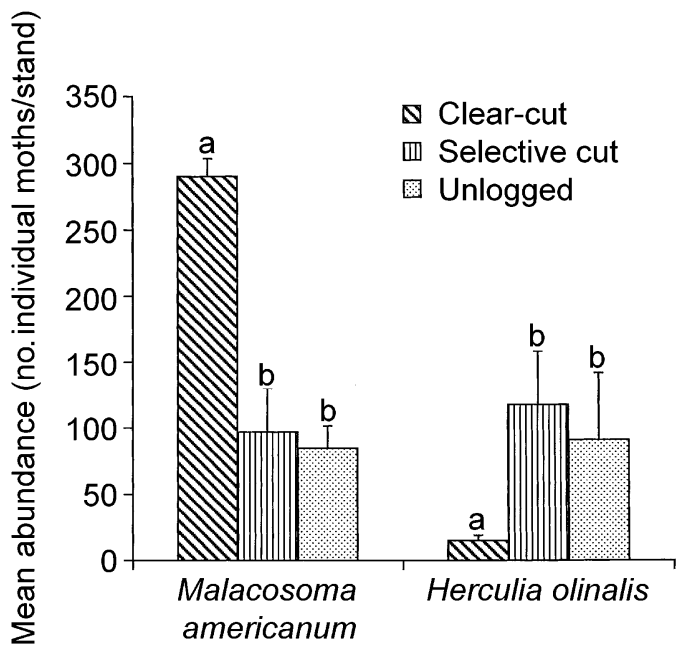

Moth species

FIG. 4. Differences in mean abundance $(+1 \mathrm{SE})$ of two potentially injurious moth species, Malacosoma americanum (Lasiocampidae) and Herculia olinalis (Pyralidae). Recovering clear-cuts supported large populations of $M$. american$u m$, whereas unlogged stands contained larger populations of the oak feeder, $H$. olinalis. Means with different letters are significantly different (Tukey's post hoc tests, $P<0.05$ ).

els except early season richness of Noctuidae (Table 6), suggesting that spatial differences in species richness apart from harvest regimes were relatively minor for all but a few moth taxa. Finally, the effects of logging on moth abundance were significant only for the late season community when significantly fewer individuals were sampled in the clear-cut compared to selectively logged or unlogged stands (Fig. 3b, Table 6).

Two of the most abundant and potentially defoliating species differed in their responses to timber harvest (Table 7). First, Malacosoma americanum (Lasiocampidae: eastern tent caterpillar) was significantly more abundant in clear-cut stands (Fig. 4), a result supported by the concordant placement of this species' favored host plant (black cherry) on the CCA ordination. Stands managed less intensively contained roughly half as

TABLE 7. Two-level nested ANOVA for differences in mean log-transformed abundances of four species whose caterpillars are considered economically injurious.

\begin{tabular}{|c|c|c|c|c|c|}
\hline \multirow[b]{2}{*}{ Species } & \multicolumn{2}{|c|}{ Harvest $(\mathrm{df}=2)$} & \multicolumn{2}{|c|}{$\begin{array}{l}\text { Drainage(harvest) } \\
(\mathrm{df}=3)(\text { error } a)\end{array}$} & \multirow{2}{*}{$\begin{array}{c}\text { Stand } \\
(\text { drainage }) \\
(\mathrm{df}=6) \\
(\text { error } b)\end{array}$} \\
\hline & MS & $F$ & MS & $F$ & \\
\hline Malacosoma americanum & 2.14 & $9.07 *$ & 0.24 & 0.24 & 0.267 \\
\hline Herculia olinalis & 4.02 & $31.9 * *$ & 0.19 & 0.14 & 0.192 \\
\hline Itame pustularia & 0.31 & 0.70 & 0.43 & 2.26 & 1.02 \\
\hline Dichomeris ligulella & 1.00 & 0.29 & 3.48 & 3.48 & 3.42 \\
\hline
\end{tabular}

Notes: Timber harvesting within a forested watershed significantly affected population sizes of two species: Malacosoma americanum (Lasiocampidae) and Herculia olinalis (Pyralidae). Error $a$ was used as the denominator in the $F$ statistic to test the main effect of harvest. Error $b$ was used to test the nested effect of Drainage(harvest) (see Sokal and Rohlf 1995). $* P<0.05 ; * * P<0.01$. 
TABLE 8. Two-level nested ANOVA for differences in mean species richness and log-transformed abundances of Lepidoptera classified into five feeding guilds (based on caterpillar host plant preference, see Methods: Data analysis: Guild classification for details).

\begin{tabular}{|c|c|c|c|c|c|}
\hline \multirow[b]{2}{*}{ Guild } & \multicolumn{2}{|c|}{ Harvest $(\mathrm{df}=2)$} & \multicolumn{2}{|c|}{$\begin{array}{l}\text { Drainage(harvest) } \\
(\mathrm{df}=3)(\text { error } a)\end{array}$} & \multirow{2}{*}{$\begin{array}{c}\text { Stand } \\
(\text { drainage }) \\
(\mathrm{df}=6) \\
(\text { error } b)\end{array}$} \\
\hline & MS & $F$ & MS & $F$ & \\
\hline \multicolumn{6}{|l|}{$\overline{\mathrm{WP}}$} \\
\hline Richness, early & 589.75 & $51.28 * *$ & 11.5 & 1.28 & 9.00 \\
\hline Richness, late & 412.75 & $67.85 * *$ & 6.08 & 0.14 & 44.75 \\
\hline Abundance, early & 0.021 & 0.48 & 0.41 & 0.61 & 0.067 \\
\hline Abundance, late & 1.22 & $11.48 *$ & 0.11 & 1.64 & 0.28 \\
\hline \multicolumn{6}{|l|}{ HERB } \\
\hline Richness, early & 6.33 & 0.77 & 8.25 & 0.73 & 11.25 \\
\hline Richness, late & 7.00 & 0.51 & 13.67 & 0.87 & 15.66 \\
\hline Abundance, early & 0.036 & 0.76 & 0.034 & 0.75 & 0.031 \\
\hline Abundance, late & 0.042 & 0.40 & 0.10 & 0.90 & 0.11 \\
\hline \multicolumn{6}{|l|}{ DET } \\
\hline Richness, early & 25.08 & 7.34 & 3.42 & 1.41 & 2.41 \\
\hline Richness, late & 16.08 & $21.44 *$ & 0.75 & 1.00 & 0.75 \\
\hline Abundance, early & 0.48 & 2.14 & 0.23 & 3.72 & 0.061 \\
\hline Abundance, late & 0.076 & 0.23 & 0.37 & $28.33 * * *$ & 0.012 \\
\hline \multicolumn{6}{|l|}{ FLM } \\
\hline Richness, early & 15.75 & $21.00 *$ & 0.75 & 1.00 & 0.75 \\
\hline Richness, late & 3.25 & 4.33 & 0.75 & 0.33 & 2.25 \\
\hline Abundance, early & 1.67 & $8.24 *$ & 0.201 & 1.14 & 0.41 \\
\hline Abundance, late & 3.19 & $53.43 * *$ & 0.059 & 0.39 & 0.15 \\
\hline \multicolumn{6}{|l|}{ GEN } \\
\hline Richness, early & 5.25 & 1.17 & 4.50 & 0.87 & 5.17 \\
\hline Richness, late & 7.00 & 1.12 & 6.25 & 1.47 & 4.25 \\
\hline Abundance, early & 0.14 & 0.67 & 0.21 & 1.13 & 0.19 \\
\hline Abundance, late & 0.076 & 0.46 & 0.16 & 1.47 & 0.11 \\
\hline
\end{tabular}

Notes: The effects of timber harvest were analyzed separately for early and late sampling periods. Guild designations are as follows: WP, woody plant feeders; HERB, herbaceous plant feeders; DET, detritivores; FLM, fungi, lichen, or moss feeders; GEN, generalist feeders utilizing at least two of the five resource classes. Error $a$ was used as the denominator in the $F$ statistic to test the main effect of harvest. Error $b$ was used to test the nested effect of Drainage(harvest) (see Sokal and Rohlf 1995).

$* P<0.05 ; * * P<0.01 ; * * * P<0.001$.

many individuals. In contrast, the specialist oak feeder Herculia olinalis (Pyralidae) was sampled at very low abundance in clear-cut stands. Selectively logged and unlogged stands contained $>10$ times as many individuals of this potentially damaging oak feeder (Fig. 4). Finally, two other abundant species, Itame pustularia (Geometridae: lesser maple spanworm moth) and Dichomeris ligulella (Gelechiidae: palmerworm moth), did not vary in abundance among forest stands (Table 7). Therefore, the postharvest response of economically damaging moths appeared to track changes in host tree importance; species attained their highest density in stands dominated by their host tree. Abundances were similar across harvest regimes for those moth species whose host trees were unaffected by logging (see Table 2). For example, I. pustularia feeds on Acer spp. (maples), which did appear to significantly vary in importance across harvest regimes (Table 2).
Effects of timber harvest on guild diversity of forest moths $(H 3 a-b)$

The differences in overall moth species richness, abundance, and community composition were largely driven by a changes within a few feeding guilds (Table 8). Woody foliage feeders (WP), detritivores, and fungi/lichen/moss feeders (FLM) had significantly higher species richness (Fig. 5a, b) and abundance (for WP and FLM guilds) in unlogged or selectively logged stands compared to the clear-cuts. Differences in woody foliage feeders showed the same phenological variation as total species richness: unlogged stands had the highest species richness in the early season (Fig. 5a), but no difference was apparent between unlogged and selectively cut stands in the late season (Fig. 5b). No differences in richness or abundance were observed among generalist feeders or species with caterpillars that feed on herbaceous vegetation (Table 8). A single 
significant effect of drainage was observed for the abundance of detritivores in the late season (Table 8). Thus, the significant differences in the total species richness of moth communities result from a decline in the number of species exploiting woody vegetation, detritus, or encrusting flora (e.g., lichens) in stands recovering from timber harvest.

Log-linear models of the response of woody foliage feeders to timber harvest did not support the prediction that specialists would be disproportionately affected by logging. As with the nested ANOVAs, log-linear models demonstrated that timber harvest significantly reduced the number of woody plant feeders $\left(\chi^{2}=6.14\right.$, $P<0.05)$. The main effect of guild classification was also significant $\left(\chi^{2}=34.91, P<0.0001\right)$, and resulted from the fact that most woody plant feeders were either generalists or specialists (few oligophages). The interaction between timber harvest and guild classification, however, was not significant $\left(\chi^{2}=0.51, P>0.50\right)$, suggesting that specialization on a single genus of host plant did not result in a greater influence of logging. The same conclusion emerged when we restricted our analyses to species feeding on oaks. This log-linear model produced significant main effects of timber harvest $\left(\chi^{2}=7.84, P<0.01\right)$ and guild classification $\left(\chi^{2}\right.$ $=72.68, P<0.0001)$, but the interaction term was not significant $\left(\chi^{2}=4.40, P>0.10\right)$. Clearly, timber harvest significantly reduced the number of oak feeders utilizing forest stands, but species specializing on oaks were not disproportionately affected by logging.

\section{Effects of landscape context on moth community composition and diversity (H4)}

In contrast to harvested stands within the managed watershed, we found little evidence for differences in overall moth biodiversity between unlogged stands occurring in different landscape contexts. We found no significant differences in overall species richness, abundance, and guild composition between unlogged and wilderness stands in either early or late sampling seasons (analyses not shown, but models were similar to those in Tables 5 and $7, P>0.15$ for tests of significance). Furthermore, there was no difference in the abundance of the four potentially defoliating species (see Table 7) between unlogged stands in managed and wilderness watersheds. Together, with the CCA (Fig. $2 \mathrm{a}, \mathrm{b})$, these results suggest that community composition may differ between unlogged stands in managed and wilderness areas, but this landscape context does not significantly influence overall species or guild diversity.

\section{DISCUSSION}

Forest stands with different levels of timber harvest differed substantially in lepidopteran community composition, species richness and abundance, and guild structure. Whereas community composition changed across all three levels of timber harvest, the effects of

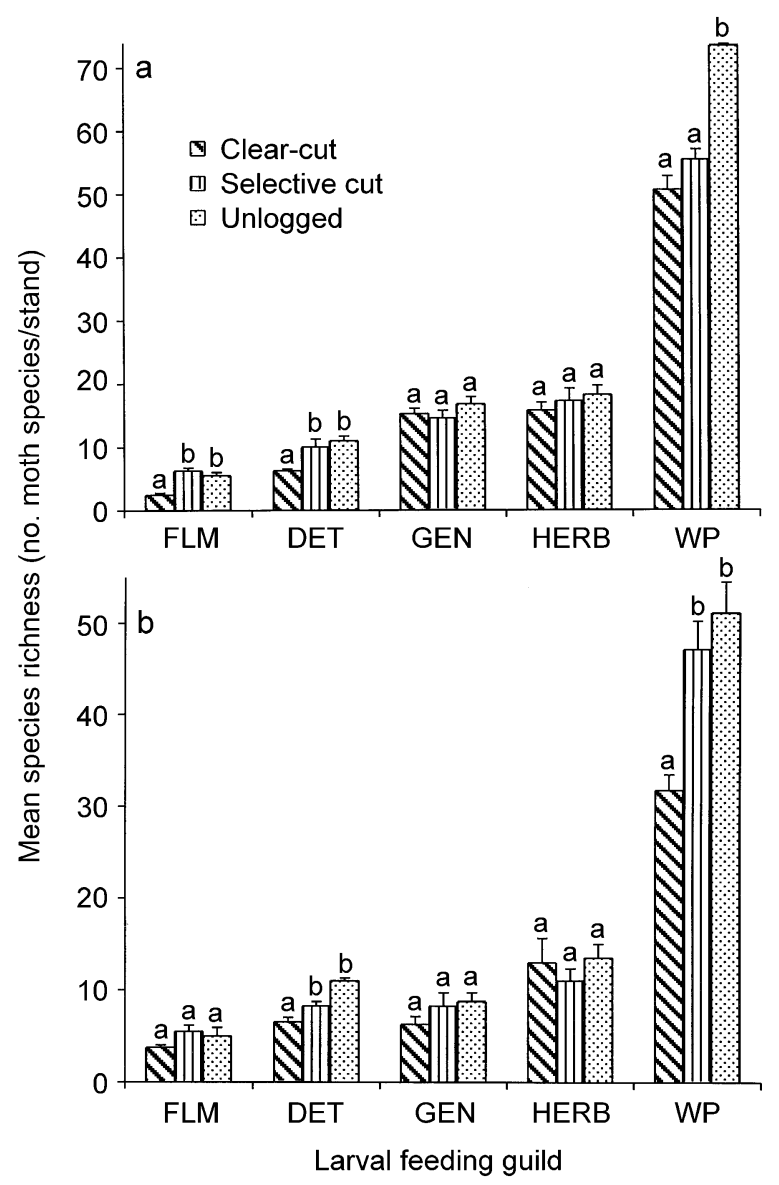

FIG. 5. Variation in species richness of moths $(+1 \mathrm{SE})$ in five feeding guilds sampled in stands recovering from different timber harvest regimes. Feeding guilds are defined as follows: FLM, fungi/lichen/mosses; DET, detritivores; GEN, generalists; HERB, graminoid or forbs; WP, woody plants (see Methods: Data analysis: Guild classification). Data are presented for (a) early and (b) late season. Means with different letters are significantly different (Tukey's post hoc tests, $P<0.05)$.

logging on species richness of forest moths were most pronounced for stands recovering from a clear-cut. Thus, our results support the observations of Hamer et al. (1997), Willott (1999), Hamer and Hill (2000), and Lewis (2001), in which logging disturbances in tropical systems appear to have a threshold effect on faunal species richness when the scale of sampling is large (e.g., watersheds). Because the intensity of timber extraction from a stand is correlated with the displacement of the stand along a seral gradient (Grieser-Jones 1997), the presence of this threshold may have a mechanistic explanation. Clear-cutting resets the successional trajectory of a stand, and early seral communities are typically impoverished for Lepidoptera (Southwood et al. 1979, Steffan-Dewenter and Tscharntke 1997). A threshold is observed because moth species richness is diminished only when the overall floristic composition of the forest habitat is significantly dis- 
placed from the initial assemblage (Intachat et al. 1997). Furthermore, because clear-cuts in Shawnee State Forest regenerate as mixed stands of red maple (Acer rubrum), yellow poplar (Liriodendron tulipiferum), and black cherry (Prunus serotina; Table 2), significant reduction in woody foliage feeding moths may be linked to a reduced diversity of host tree species within recovering patches (Neuvonen and Niemelä 1981).

In contrast to clear-cutting, selective cuts do not alter a forest from its predisturbance seral stage as significantly as a clear-cutting. Rather, selective logging creates gaps of varying size, mimicking (but not replicating) natural gap dynamics within forest stands (Smith et al. 1997, Willott 1999). Both natural and silvicultural gaps alter local light and microclimate attributes of forest patches and frequently serve to release understory species from arrested growth (Runkle 1982, 1991, Grieser-Jones 1997). Compared to natural gap dynamics, however, selective timber harvest typically singles out one or two genera for removal (e.g., Quercus, Liriodendron; Smith et al. 1997; W. Oney, personal communication) and usually occurs at different time intervals and stand locations. Thus, selective logging favors an increase in understory diversity and tree regeneration, but also changes crown dominance patterns compared to uncut stands. In Shawnee State Forest, selectively cut stands were generally similar to unlogged stands in terms of moth species richness, abundance, or guild diversity. Community composition of moths, however, differed between the two treatments. We suggest that a species replacement process may occur following selective timber harvest because (1) particular tree species are removed from forest stands, reducing host plant availability for some species, and (2) understory saplings and opportunistic forbs rapidly exploit gaps creating habitat for colonization by new moth species. Thus, selectively logged stands contained a mixture of moth and tree species characteristic of both unlogged and clear-cut stands (Table 2, Fig. 2a, b).

Aside from broad changes in community composition, logging significantly influenced individual species dynamics. For $M$. americanum and $H$. olinalis, abundance appeared to be correlated with host plant occurrence. Thus, clear-cuts contained large populations of the cherry feeder $M$. americanum and small populations of the oak feeder $H$. olinalis. Improvement cutting to remove cherry from recovering clear-cuts is one potential mechanism for managing $M$. americanum outbreaks (see Fitzgerald [1995]), but selective logging of damaged oaks appeared to have little affect on $H$. olinalis populations. The management of a forested landscape as a heterogeneous mosaic effectively isolates even-aged stands from one another, so that natural enemies of certain pests (e.g., parasitoids) may have difficulty in tracking local outbreaks (Roland and Taylor 1997). In addition to host plant occurrence (i.e., quan- tity), moth species dynamics are frequently modified by variation in host plant quality, which changes on a species-specific basis throughout forest regeneration (Price et al. 1995, Ostaff and Quiring 2000). Finally, changes in species distribution or population size in response to disturbance have yet to be examined for those species with caterpillars that use food sources other than plants (i.e., lichenivores, detritivores), but may be attributable to postlogging changes in microclimate, light regime, or litter availability (e.g., Rolstad et al. 2001).

Forest moth communities are also influenced by broad-scale variation in floristic composition and the spatial heterogeneity of plant communities (Robinson and Tuck 1993, Radeloff et al. 2000, Summerville et al. 2001). In our study, moth community composition of unlogged stands in a managed watershed differed from community composition in wilderness stands in an unmanaged watershed. Our experimental design lacks the replication of watersheds necessary for strong inferences on broad-scale patterns, but several alternative processes might be responsible. First, community divergence with increasing geographic distance (e.g., distance decay) is an inevitable consequence of dwindling spatial similarity among abiotic and biotic variables (Wiens 1989, Summerville et al. 2001). Thus, the dissimilarity between unlogged and wilderness stands may be attributable to unmeasured environmental differences between the two watersheds, rather than to habitat management effects. Second, many moth and tree species in remnant stands within a logged system may be more characteristic of edges or ecotones than forest interiors (Grieser-Jones 1997, Spitzer et al. 1997, Willott 1999). Our canonical correspondence analysis CCA demonstrated that wilderness stands contained a higher diversity of tree species compared to unlogged stands within a managed compartment. Thus, although numbers of moth species did not differ among these stands, differences in plant species diversity might influence the moth species composition in the two watersheds. For example, Ford et al. (2000) demonstrated that disturbance in the matrix surrounding forest remnants influenced plant diversity within remnants. Thus, the relative proportion of harvested stands in the surrounding landscape may influence the lepidopteran community composition within unlogged stands. Greater replication of this study at the watershed scale will be required to distinguish among the relative contributions of these two processes. Finally, there is some evidence that logging disrupts vertical stratification of lepidopteran communities in tropical forest systems far beyond the zone of disturbance (DeVries et al. 1997). Although we lack the data to test this hypothesis, it suggests an interesting role for the matrix in altering the biodiversity in habitat remnants.

Regardless of which process is responsible for broadscale differences in community composition, unlogged stands alone may not be sufficient for forest moth spe- 
cies in managed systems. Indeed, there may be nearly as much variation among unlogged stands within the harvested watershed as there is between the unmanaged and wilderness landscapes. More research is required to assess both short- and long-term consequences of logging on local moth community structure and how remnant forest patches accumulate woodland species from the regional species pool. Many species of Lepidoptera move surprisingly short distances in their lifetimes (e.g., Nieminen 1986, Doak 2000), and are unlikely to colonize patches $>1 \mathrm{~km}$ from a source. For these species, the number, size, and spatial arrangement of unlogged refugia will likely determine future moth community structure. In contrast, colonization probability with large dispersal distances largely should be unaffected by the spatial arrangement of remnant patches (Fahrig and Paloheimo 1988). Thus, when unlogged refugia are retained in managed systems, but remain relatively isolated, their moth communities are expected to diverge: each patch may sample a small subset of strong dispersers, but will also contain a potentially large and unique set of weak fliers emigrating from nearby habitats. A management strategy that emphasizes selective logging rather than clear-cutting of forest stands should increase woodland connectivity and may help prevent faunal divergence or relaxation within unlogged patches.

In conclusion, the long-term maintenance of biodiversity in managed landscapes may ultimately depend on successful regeneration of harvested patches to precut floristic composition. Natural regeneration of oaks and hickories is slow on clear-cut Appalachian uplands (e.g., Arthur et al. 1997), and there continues to be debate regarding whether forest understory communities ever recover from logging (Duffy and Meier 1992, Ford et al. 2000). New silvicultural techniques and assessments of mast production hold promise for increasing the recovery of oaks and hickories in postharvest stands (Larsen and Johnson 1998, Brose et al. 1999, Greenberg 2000), and it remains to be seen if animal communities will respond in kind. Finally, we note that many of our findings are likely linked to processes operating at specific spatial scales (among drainages and watersheds). Hamer and Hill (2000) concluded that differences in the spatial extent of a sampling design change the interpretation of the effects of logging on biodiversity independently of the scale of the disturbance. For example, in the tropics, several studies reviewed by the authors failed to show an effect of logging on biodiversity when the scale of sampling was smaller than ours $(<1 \mathrm{ha})$. At spatial scales much greater than ours $\left(>10 \mathrm{~km}^{2}\right)$, however, Hamer and Hill (2000) hypothesize that logging may increase regional biodiversity by contributing to greater species turnover ( $\beta$-diversity) among disturbed patches compared to among unlogged stands. Our examination of lepidopteran biodiversity suggests that current logging practices significantly alter community composition and species diversity of Lepidoptera within watersheds. Further studies are required to assess how lepidopteran biodiversity responds to management practices over broader spatial scales.

\section{ACKNOWLEDGMENTS}

Funding for this research was provided by grants from the Ohio Board of Regents Research Challenge Program, the Ohio Biological Survey, and Sigma Xi. We thank M. Boulware, N. Anderson, C. Yeager, C. Poling, and B. Clarke for their valuable assistance in the field and with specimen curation. E. Metzler, G. Balogh, L. Gibson, J. Brown, M. Sabourin, and S. Passoa lent their considerable expertise to species determinations. M. Vincent provided taxonomic assistance for plant species identifications. We thank D. Gorchov, O. Loucks, R. Blair, D. Claussen, J. Veech, D. Golden, J. Gering, R. Robbins, D. Peterson, and two anonymous reviewers for insightful discussion and comments on the ideas presented in this manuscript. Finally, we extend our sincere appreciation to D. Karas and W. Oney for permission to sample Lepidoptera in Shawnee State Forest.

\section{Literature Cited}

Andersson, F. O., K. H. Feger, R. F. Hüttl, N. Kräuchi, L. Mattsson, O. Sallnäs, and K. Sjöberg. 2000. Forest ecosystem research-priorities for Europe. Forest Ecology and Management 132:111-119.

Arthur, M. A., R. N. Muller, and S. Costello. 1997. Species composition in a central hardwood forest in Kentucky 11 years after clear-cutting. American Midland Naturalist 137: 274-281.

Bhuju, D. R., and M. Ohsawa. 2001. Patch implications in the maintenance of species richness in an isolated forest site. Biological Conservation 98:117-125.

Blair, R. B. 1999. Birds and butterflies along an urban gradient: surrogate taxa for assessing biodiversity? Ecological Applications 9:164-170.

Boerner, R. E. J., and J. G. Kooser. 1989. Leaf litter redistribution among forest patches within an Allegheny Plateau watershed. Landscape Ecology 2:81-92.

Bonham, C. D. 1989. Measurements for terrestrial vegetation. Wiley and Sons, New York, New York, USA.

Braun, A. F. 1963. The genus Bucculatrix in America north of Mexico. Memoirs of the American Entomological Society 18:1-261.

Braun, A. F. 1972. Tischeriidae of America north of Mexico. Memoirs of the American Entomological Society 28:1-148.

Braun, E. L. 1961. Woody plants of Ohio. Haefner Press, New York, New York, USA.

Brose, P. H., D. H. Van Lear, and P. D. Keyser. 1999. A shelterwood-burn technique for regenerating productive upland oak sites in the Piedmont region. Southern Journal of Applied Forestry 23:158-163.

Chey, V. K., J. D. Holloway, and M. R. Speight. 1997. Diversity of moths in forest plantations and natural forests in Sabah. Bulletin of Entomological Research 87:371-385.

Connell, J. H. 1978. Diversity in tropical rainforests and coral reefs. Science 199:1302-1310.

Covell, C. 1983. Eastern moths. Houghton-Mifflin, New York, New York, USA.

DeVries, P. J., D. Murray, and R. Lande. 1997. Species diversity in vertical, horizontal, and temporal dimensions of a fruit-feeding butterfly community in an Ecuadorian rainforest. Biological Journal of the Linnean Society 62:343364.

Doak, P. 2000. Population consequences of restricted dispersal for an insect herbivore in a subdivided habitat. Ecology 81:1828-1841.

Dominick, R. B., D. C. Ferguson, J. G. Franclemont, R. W. Hodges, and E. G. Monroe, editors. 1976. The moths of 
America north of Mexico. Wedge Entomological Foundation, E. W. Classey, London, UK.

Drapeau, P., A. Leduc, J. F. Giroux, J. P. Savard, Y. Bergeron, and W. L. Vickery. 2000. Landscape-scale disturbances and changes in bird communities of boreal mixed-wood forests. Ecological Monographs 70:423-444.

Duffy, C. D., and A. J. Meier. 1992. Do Appalachian herbaceous understories ever recover from clearcutting? Conservation Biology 6:196-201.

Ehrlich, P. R. 1996. Conservation in temperate forests: what do we need to know and do? Forest Ecology and Management 85:9-19.

Fahrig, L., and J. Paloheimo. 1988. Effects of spatial arrangement of habitat patches on local population size. Ecology 69:468-475.

Fitzgerald, T. D. 1995. The tent caterpillars. Cornell University Press, Ithaca, New York, USA.

Forbes, W. T. M. 1923. The Lepidoptera of New York and neighboring states: primitive forms. Cornell University Agricultural Experiment Station, Ithaca, New York, USA.

Ford, W. M., R. H. Odom, P. E. Hale, B. R. Chapman. 2000. Stand-age, stand characteristics, and landform effects on understory herbaceous communities in southern Appalachian cove-hardwoods. Forest Ecology and Management 93:237-246.

Franklin, J. F. 1988. Structural and functional diversity in temperate forests. Pages 166-175 in E. O. Wilson, editor. Biodiversity. National Academy Press, Washington, D.C., USA.

Goebel, P. C., and D. M. Hix. 1996. Development of mixedoak forests in southeastern Ohio: a comparison of secondgrowth and old-growth forests. Forest Ecology and Management 84:1-21.

Greenberg, C. H. 2000. Individual variation in acorn production by five species of southern Appalachian oaks. Forest Ecology and Management 132:119-210.

Greig-Smith, P. 1983. Quantitative plant ecology. University of California Press, Los Angeles, California, USA.

Grieser-Jones, A. 1997. Timber production and biodiversity conservation in tropical rain forests. Cambridge University Press, Cambridge, UK.

Gustafson, E. J. 1996. Expanding the scale of forest management: allocating timber harvests in space and time. Forest Ecology and Management 87:27-39.

Halpern, C. B., and T. A. Spies. 1995. Plant species diversity in natural and managed forests of the Pacific Northwest. Ecological Applications 5:913-934.

Hamer, K. C., and J. K. Hill. 2000. Scale-dependent effects of habitat disturbance on species richness in tropical forests. Conservation Biology 14:1435-1440.

Hamer, K. C., J. K. Hill, L. A. Lace, and A. M. Langan. 1997. Ecological and biogeographical effects of forest disturbance on tropical butterflies of Sumba, Indonesia. Journal of Biogeography 24:67-75.

Hammond, P. C., and J. C. Miller. 1998. Comparison of the biodiversity of Lepidoptera within three forested ecosystems. Annals of the Entomological Society of America 91: 323-328.

Heinrich, C. 1956. American moths of the subfamily Phyticinae. Smithsonian Institution, Washington, D.C., USA.

Hill, J. K., K. C. Hamer, L. A. Lace, and W. M. T. Banham. 1995. Effects of selective logging on tropical forest butterflies on Buru, Indonesia. Journal of Applied Ecology 32: $754-760$.

Holloway, J. D. 1989. Moths. Pages 437-453 in H. Leith and M. J. A. Werger, editors. Tropical forest ecosystems of the world. Elsevier, Amsterdam, The Netherlands.

Holloway, J. D., A. H. Kirk-Spriggs, and V. K. Chey. 1992. The response of some rain forest insect groups to logging and conversion to plantation. Philosophical Transactions of the Royal Society of London Series B 335:425-436.

Intachat, J., J. D. Holloway, and M. R. Speight. 1997. The effects of different forest management practices on geometrid moth populations and their diversity in peninsular Malaysia. Journal of Tropical Forest Science 9:411-430.

Jongman, R. H. G., C. J. F. ter Braak, and O. F. R. Tongeren, editors. 1995. Data analysis in community and landscape ecology. Cambridge University Press, Cambridge, UK.

Kerr, J. T., A. Sugar, and L. Packer. 2000. Indicator taxa, rapid biodiversity assessment, and nestedness in an endangered ecosystem. Conservation Biology 14:1726-1734.

Kitching, R. L., A. G. Orr, L. Thalib, H. Mitchell, M. S. Hopkins, and A. W. Graham. 2000. Moth assemblages as indicators of environmental quality of Australian rain forest. Journal of Applied Ecology 37:284-297.

Larsen, D. R., and P. S. Johnson. 1998. Linking the ecology of natural oak regeneration to silviculture. Forest Ecology and Management 106:1-7.

Latham, R. E., and R. E. Ricklefs. 1993. Continental comparisons of temperate-zone tree species diversity. Pages 294-314 in R.E. Ricklefs and D. Schluter, editors. Species diversity in ecological communities, University of Chicago Press, Chicago, Illinios, USA.

Lepš, J., K. Spitzer, and J. Jarŏs. 1998. Food plants, species composition, and variability of the moth community in an undisturbed forest. Oikos 81:538-48.

Lewis, O. T. 2001. Effect of experimental selective logging on tropical butterflies. Conservation Biology 15:389-400.

Lousier, J. D. 2000. Northern forest management issues. Forest Ecology and Management 133:1-3.

Lubchenco, J., et al. 1991. The sustainable biosphere initiative: an ecological research agenda. Ecology 72:371-412.

MacKay, M. R. 1959. Larvae of the North American Olethreutidae (Lepidoptera). Memoirs of the Entomological Society of Canada S10:1-338.

MacKay, M. R. 1962. Larvae of the North American Tortricinae (Lepidoptera: Tortricidae). Memoirs of the Entomological Society of Canada S28:1-182.

McCarthy, B. C., C. J. Small, and D. Rubino. 2001. Composition, structure, and dynamics of Dysart Woods, an oldgrowth mixed mesophytic forest of southeastern Ohio. Forest Ecology and Management 140:193-213.

McGuffin, W. C. 1972. Guide to the Geometridae of Canada (Lepidoptera) II. Subfamily Ennominae 1. Memoirs of the Entomological Society of Canada 86:1-159.

McGuffin, W. C. 1977. Guide to the Geometridae of Canada (Lepidoptera) II. Subfamily Ennominae 2. Memoirs of the Entomological Society of Canada 101:1-191.

McGuffin, W. C. 1981. Guide to the Geometridae of Canada (Lepidoptera) II. Subfamily Ennominae 3. Memoirs of the Entomological Society of Canada 117:1-153.

McGuffin, W. C. 1987. Guide to the Geometridae of Canada (Lepidoptera) II. Subfamily Ennominae 4. Memoirs of the Entomological Society of Canada 138:1-182.

Medley, K. E., B. W. Okey, G. W. Barrett, M. F. Lucas, and W. H. Renwick. 1995. Landscape change with agricultural intensification in a rural watershed, southwestern Ohio, USA. Landscape Ecology 10:161-176.

Miller, W. E. 1987. Guide to the Olethreutine moths of midland North America (Tortricidae). USDA Handbook 660, Washington, D.C., USA.

MJM Software Design. 1999. PC-ORD: multivariate analysis of ecological data (Ver. 4.0). MJM Software, Gleneden Beach, Oregon, USA.

Mrosek, T. 2001. Developing and testing of a method for analysis and assessment of multiple forest use from a conservation perspective. Forest Ecology and Management 140:65-74.

Nagaike, T., T. Kamitani, and T. Nakashizuka. 1999. The 
effect of shelterwood logging on the diversity of plant species in a beech (Fagus crenata) forest in Japan. Forest Ecology and Management 118:161-171.

Neter, J., W. Wasserman, and M. Kutner. 1990. Applied linear statistical models. Third edition. Irwin, Homewood, Illinois, USA.

Neuvonen, S., and P. Niemelä. 1981. Species richness of macrolepidoptera on Finnish deciduous trees and shrubs. Oecologia 51:364-370.

Nieminen, M. 1986. Migration of a moth species in a network of small islands. Oecologia 108:643-651.

Norton, T. W. 1996. Conservation of biological diversity in temperate and boreal forest ecosystems. Forest Ecology and Management 85:1-7.

Nummelin, M., and I. Hanski. 1989. Dung beetles of Kibale forest, Uganda: comparison between virgin and managed forests. Journal of Tropical Ecology 5:349-352.

Oliver, I., and A. J. Beattie. 1996. Designing a cost-effective invertebrate survey: a test of methods for rapid assessment of biodiversity. Ecological Applications 6:594-607.

Ostaff, D. P., and D. T. Quiring. 2000. Role of host plant in the decline of populations of a specialist herbivore, the spruce bud moth. Journal of Animal Ecology 69:263-273.

Perry, D. 1994. Forest ecosystems. Johns Hopkins University Press, Baltimore, Maryland, USA.

Price, P. W., I. R. Diniz, H. C. Morais, and E. S. A. Marques. 1995. Abundance of insect herbivore species in the tropics: the high local richness of rare species. Biotropica 27:468478.

Radeloff, V. C., D. J. Mladenoff, and M. S. Boyce. 2000. The changing relation of landscape patterns and jack budworm populations during an outbreak. Oikos 90:417-430.

Rings, R. W., E. H. Metzler, F. J. Arnold, and D. H. Harris. 1992. The owlet moths of Ohio (Lepidoptera: Noctuidae). Ohio Biological Survey Bulletin New Series. 9:1-219.

Robinson, G. S., and K. R. Tuck. 1993. Diversity and faunistics of small moths (microlepidoptera) in Bornean rainforest. Ecological Entomology 18:385-393.

Roland, J., and P. D. Taylor. 1997. Insect parasitoid species respond to forest structure at different spatial scales. Nature 386:710-713.

Rolstad, J., I. Gjerde, K. O. Storaunet, and E. Rolstad. 2001. Epiphytic lichens in Norwegian coastal spruce forest: historic logging and present forest structure. Ecological Applications 11:421-236.

Runkle, J. 1982. Gap regeneration in some old-growth forests of the Eastern USA. Ecology 62:1041-1051.

Runkle, J. 1991. Gap dynamics of old-growth Eastern forests: management implications. Natural Areas Journal 11:1925.

SAS Institute. 1996. SAS for Windows: Release 6.12. SAS Institute, Cary, Indiana, USA.

Schieck, J., K. Stuart-Smith, and M. Norton. 2000. Bird communities are affected by amount and dispersion of vegetation retained in mixed wood boreal forest harvest areas. Forest Ecology and Management 126:239-254.

Schowalter, T., D. Crossley, Jr., and W. Hargrove. 1986. Herbivory in forest ecosystems. Annual Review of Entomology 31:177-196.

Smith, D. M., B. Larson, M. J. Kelty, and P. M. S. Ashton.
1997. The practice of silviculture. John Wiley and Sons, New York, New York, USA.

Sokal, R., and F. Rohlf. 1995. Biometry. W. H. Freeman, New York, New York, USA.

Southwood, T. R. E. 1978. Ecological methods. Chapman and Hall, London, UK.

Southwood, T. R. E., V. K. Brown, and T. C. Reader. 1979. The relationship of plant and insect diversities in succession. Biological Journal of the Linnean Society 12:327348 .

Spitzer, K., J. Jarŏs, J. Havelka, and J. Lepš. 1997. Effect of small-scale disturbance on butterfly communities of an indochinese montane rainforest. Biological Conservation 80: $9-15$.

Steffan-Dewenter, I., and T. Tscharntke. 1997. Early succession of butterfly and plant communities on set-aside fields. Oecologia 109:294-302.

Stork, N. E. 1988. Insect diversity: facts, fiction, and speculation. Biological Journal of the Linnean Society 35:321337.

Summerville, K. S., J. J. Jacquot, and R. F. Stander. 1999. Preliminary checklist of the moths of Butler County, Ohio. Ohio Journal of Science 99:66-76.

Summerville, K. S., E. H. Metzler, and T. O. Crist. 2001. Diversity of forest Lepidoptera at local and regional scales: how heterogeneous is the fauna? Annals of the Entomological Society of America 94:583-591.

ter Braak, C. J. F. 1986. Canonical correspondence analysis: a new eigenvector technique for multivariate direct gradient analysis. Ecology 67:1167-1179.

ter Braak, C. J. F. 1994. Canonical community ordination. Part I: basic theory and linear methods. Ecoscience 1:127140 .

Thiollay, J. M. 1997. Disturbance, selective logging, and bird diversity: a Neotropical forest study. Biodiversity and Conservation 6:1155-1173.

Thomas, A. W., and G. M. Thomas. 1994. Sampling strategies for estimating moth species diversity using a light trap in a northeastern softwood forest. Journal of the Lepidopterists Society 48:85-105.

Tietz, H. M. 1972. An index to the described life histories, early stages, and hosts of the macrolepidoptera of the continental United States and Canada. Allyn Museum of Entomology, Los Angeles, California, USA.

Usher, M. B., and S. W. J. Keiller. 1998. The macrolepidoptera of farm woodlands: determinants of diversity and community structure. Biodiversity and Conservation 7:725748 .

Wiens, J. A. 1989. Spatial scaling in ecology. Functional Ecology 3:385-397.

Wilkinson, C., and M. J. Scoble. 1979. The Nepticulidae of Canada. Memoirs of the Entomological Society of Canada 107: $1-130$.

Willott, S. J. 1999. The effects of selective logging on the distribution of moths in a Bornean rainforest. Philosophical Transactions of the Royal Society of London Series B 354: 1783-1790

Yela, J. L., and M. Holyoak. 1997. Effects of moonlight and meteorological factors on light and bait trap catches of noctuid moths. Environmental Entomology 26:1283-1290. 